\title{
Bimbingan Keagamaan Dalam Upaya Pencegahan Kenakalan Remaja
}

\author{
Ageng Radiyah Nooralmira ${ }^{1}$, Yudi Guntara ${ }^{2}$ \\ ${ }^{1}$ Prodi bimbingan penyuluhan islam, Ciamis, STID Sirnarasa \\ agengrady04@gmail.com
}

\begin{abstract}
ABSTRAK
Masa remaja adalah masa transisi perkembangan antara masa kanak-kanak dan masa dewasa. perilaku remaja yang mudah terpengaruh memerlukan bimbingan keagamaan agar remaja tidak mudah terpengaruh kepada hal negatif seperti kenakalan remaja yang akan merugikan dirinya sendiri dimasa yang akan datang. Penelitian ini bertujuan untuk mengetahui program, proses, hasil serta faktor kendala dan pendukung dalam bimbingan keagamaan. Adapun pendekatan penelitian menggunakan pendekatan kualitatif deskriptif dengan teknik pengumpulan datanya observasi, wawancara dan dokumentasi. Teknik analisis data kualitatif berupa reduksi data, penyajian data dan penarikan kesimpulan. Hasil penelitian yang didapatkan terdapat beberapa program bimbingan keagamaan dalam upaya pencegahan kenakalan remaja yaitu dimulai dari program harian, mingguan, bulanan dan tahunan seperti pelajaran jurumiyah, sejarah islam, tauhid dan fiqih adapun kesenian islam dan tradisional serta kegiatan olahraga, pusat informasi konseling remaja, pengajian bulanan, ziarah, kuliah subuh, membimbing pengajian DTA, Baros fun competitions, pentas seni dan lomba ceramah.
\end{abstract}

Kata Kunci : Bimbingan Keagamaan; Remaja; Kenakalan Remaja;

\section{ABSTRACT}

Adolescence is a developmental transition period between childhood and adulthood. The behavior of teenagers who are easily influenced requires religious guidance so that they are not easily influenced by negative things such as juvenile delinquency which will harm themselves in the future. This study aims to determine the program, process, results as well as the constraint and supporting factors in religious guidance. The research approach uses a descriptive qualitative

Diterima: Agustus 2021. Disetujui: September 2021. Dipublikasikan: September 2021 | 32 
Bimbingan Keagamaan Dalam Upaya Pencegahan Kenakalan Remaja approach with data collection techniques of observation, interviews and documentation. Qualitative data analysis techniques in the form of data reduction, data presentation and drawing conclusions. The results obtained are several religious guidance programs in an effort to prevent juvenile delinquency, starting from daily, weekly, monthly and yearly programs such as jurimiyah lessons, Islamic history, monotheism and figh as for Islamic and traditional arts and sports activities, youth counseling information centers, recitations monthly visits, pilgrimages, morning lectures, guiding DTA studies, Baros fun competitions, art performances and lecture competitions.

Keywords: Religious guidance; teenager; juvenile delinquency;

\section{PENDAHULUAN}

Keremajaan merupakan masa kemajuan formatif antara masa remaja dan dewasa yang sebagian besar dimulai pada usia 12 tahun atau 13 tahun. Peningkatan yang dimaksud adalah kemajuan yang terjadi pada usia harapan hidup. Perkembangan ini dapat terjadi secara kuantitatif, seperti peningkatan tinggi badan atau berat badan, dan secara subjektif, seperti perubahan perspektif dari substansial ke teoritis. Perbaikan eksistensi manusia terjadi dalam berbagai perspektif (Elibrahim M. Nur, 2011:1).

Desa Ciomas merupakan desa yang berada di wilayah Panjalu, Kabupaten Ciamis. Berdasarkan data yang diperoleh pada tanggal 27 Agustus 2020 dari Usup Sukmana selaku Kaur. administrasi dan umum desa Ciomas, bahwa jumlah penduduk desa Ciomas sampai dengan Desember 2018 adalah sebanyak 7.664 jiwa yang dibagi menjadi dua bagian, yaitu jumlah penduduk laki-laki sebanyak 3.866 jiwa dan penduduk perempuan sebanyak 3.798 jiwa.

Informasi kependudukan menurut kelompok umur memasuki masa remaja adalah sebagai berikut, umur 10-14 tahun terdapat 575 orang, umur 15-19 tahun terdapat 555 orang, umur 20-24 tahun terdapat 566 orang. Salah satu Dusun yang terletak di Desa Ciomas adalah Dusun Baros dengan jumlah penduduk 756 jiwa terdiri dari 411 penduduk lakilaki serta 345 jiwa penduduk perempuan. 
Ageng RN. Yudi G

Perilaku buruk remaja disebut juga kenakalan remaja. Kenakalan remaja dicirikan sebagai perilaku keganasan/kenakal yang dilakukan oleh remaja. Remaja berasal dari bahasa latin "juvenilis" berarti tidak dipedulikan, diabaikan, yang kemudian diperluas dengan arti licik, kriminal, mengganggu norma, dan lain-lain. Kenakalan dicirikan sebagai pelanggaran, dan kejahatan yang dilaksanakan oleh anak di bawah umur 22 tahun (Vina, 2018:5).

Banyaknya kasus kenakalan remaja yang terjadi sangat memprihatinkan dan banyak sekali media yang memberitakan kasus-kasus kenakalan remaja diantaranya penyalahgunaan narkoba, seks bebas, anak di bawah umur yang sudah merokok, tawuran, mabuk-mabukan, balapan liar dan masih banyak lagi kasus kenakalan remaja lainnya. Data yang diambil pada 15 April 2020 dari situs resmi Badan Pusat Statistik (BPS) yang bersumber dari dinas sosial provinsi Jawa Barat bahwa pada tahun 2016 terdapat 2.592 kasus kenakalan remaja dan 5.935 kasus penyalahgunaan narkoba. Sedangkan di Kabupaten Ciamis terdapat 34 kasus kenakalan remaja dan 33 kasus penyalahgunaan narkoba.

Selain itu banyak kasus anak di bawah umur yang merokok, data terakhir dari Global Youth Tobacco Survey (GYTS) tahun 2019 menunjukkan bahwa 40,6\% pelajar di Indonesia (usia 13-15 tahun), 2 dari 3 anak lakilaki, dan hampir 1 dari 5 anak perempuan telah menggunakan produk tembakau: 19,2\% siswa saat ini merokok dan dari jumlah tersebut, 60,6\% bahkan tidak dicegah untuk membeli rokok karena usia mereka, dan dua pertiga dari mereka dapat membeli rokok eceran.

Berdasarkan data kenakalan remaja di atas, masih banyak anak muda kurang tepat dalam bersosialisasi, namun hal ini berbeda dengan remaja di dusun Baros, dikarenakan dusun Baros memiliki Yayasan Riyadhul Jannah yang memiliki lembaga bimbingan keagamaan khusus remaja yang diberi nama Remaja Islam Masjid Baros (RIMBA).

Hasil dari wawancara dengan Nia Kurniasih sebagai pembimbing keagamaan di Remaja Islam Masjid Baros (RIMBA) mengatakan bahwa 
Bimbingan Keagamaan Dalam Upaya Pencegahan Kenakalan Remaja jumlah remaja yang berada di Remaja Islam Masjid Baros adalah 58 orang. Remaja yang mengikuti bimbingan keagamaan di Remaja Islam Masjid Baros merupakan semua remaja yang berada di lingkungan sekitar yang kemudian dibagi menjadi dua kelas yaitu taruna satu untuk tingkat SMP dan taruna dua untuk tingkat SMA (Kurniasih, Nia. Wawancara Pribadi. 04 Januari 2021).

Anggota Remaja Islam Masjid Baros ini terdiri dari remaja tingkatan Sekolah Menengah Pertama hingga Sekolah Menengah Atas, berdasarkan hasil wawancara dengan salah satu remaja yang masih aktif mengikuti bimbingan keagamaan di Remaja Islam Masjid Baros adalah keinginan dalam diri sendiri karena bimbingan keagamaan yang ada di Remaja Islam Masjid Baros banyak kegiatan positif yang bisa melatih kemampuan dalam memimpin, bekerjasama dan saling membantu karena pembelajaran keagamaan di sekolah saja tidak cukup. (Nuraini, Inda. Wawancara Pribadi. 05 Januari 2021)

Berdasarkan latar belakang di atas, peneliti tertarik untuk meneliti tentang bimbingan keagamaan di Remaja Islam Masjid Baros khususnya bimbingan keagamaan pada remaja. Ada pun judul penelitian ini yaitu bimbingan keagamaan dalam upaya pencegahan kenakalan remaja.

Skripsi yang membahas tentang bimbingan keagamaan salah satunya adalah skripsi Fitri Rahmawati, dengan judul "Bimbingan Keagamaan Untuk Meningkatkan Religiusitas Siswa SMA N 8 Yogyakarta Tahun 2017" Hasil dari penelian menunjukkan bahwa bimbingan keagamaan dan dunia pendidikan sangatlah penting dalam meningkatkan religiusitas siswa SMA N 8 Yogyakarta tahun 2017. Ini dibuktikan dengan SMA N 8 Yogyakarta adalah sekolah umum tetapi tidak mengesampingkan pendidikan keagamaan untuk meningkatkan religiusitas siswa seperti membaca kitab suci agama, sholat dan akhlak.

Persamaan antara penelitian Fitri Rahmawati dengan penelitian yang akan diteliti yaitu sama-sama meneliti tentang bimbingan keagamaan (variabel $\mathrm{x}$ ), sedangkan perbedaan penelitian terletak di variabel y dan tempat penelitian. Penelitian Fitri Rahmawati variabel y nya adalah 
Ageng RN. Yudi G

religiusitas siswa dan penelitiannya dilakukan di sekolah yaitu SMA, sedangkan variabel y yang akan diteliti adalah kenakalan remaja yang sasarannya adalah remaja dan bertempat di Madrasah.

Selain itu skripsi yang membahas tentang kenakalan remaja salah satunya adalah skripsi Ike Wulandari dengan judul "Kebijakan sekolah dalam mengatasi kenakalan remaja di SMA Negeri 6 Yogyakarta tahun 2014". Hasil penelitian menunjukkan bahwa berbagai pengaturan memiliki pilihan untuk mengatasi kenakalan remaja, terutama perkelahian. Akibat dari pemeriksaan ditemukan beberapa pendekatan sekolah dalam mengatasi kenakalan remaja diantaranya disiplin yang berat, akhir dari penelitian ini adalah bahwa kenakalan remaja di SMA Negeri 6 Yogyakarta tahun 2014 dapat diatasi oleh adanya strategi sekolah.

Persamaan antara penelitian Ike Wulandari dengan penelitian yang akan diteliti yaitu kenakalan remaja, perbedaannya yaitu pada variabel $x$ dan tempat penelitiannya. Skripsi Ike Wulandari, variabel $\mathrm{x}$ nya adalah strategi sekolah dapat mengelola kenakalan remaja dan penelitiannya dilakukan di sekolah menengah sedangkan penelitian yang akan diteliti variabel $x$ nya adalah bimbingan keagamaan dan akan dilakukan di Madrosah.

Adapun pertanyaan penelitian ini adalah sebagai berikut: a). Apa program bimbingan keagamaan yang ada di Remaja Islam Masjid Baros?; b). Bagaimana pelaksanaan pencegahan kenakalan remaja di Remaja Islam Masjid Baros?; c). Apa saja faktor kendala dan pendukung bimbingan keagamaan dalam upaya pencegahan kenakalan remaja di Remaja Islam Masjid Baros?; d). Bagaimana hasil bimbingan keagamaan dalam upaya pencegahan kenakalan remaja di Remaja Islam Masjid Baros?. Penelitian ini menggunakan metode kualitatif deskriptif.

\section{LANDASAN TEORITIS}

Bimbingan adalah interpretasi dari tuntunan dalam bahasa Inggris, tuntunan berasal dari kata dalam bahasa Inggris "guide" atau "to guide" 
Bimbingan Keagamaan Dalam Upaya Pencegahan Kenakalan Remaja yang bermaksud menunjukkan, membimbing atau membimbing orang lain ke jalan yang benar. Jadi kata tuntunan mengandung arti memberi petunjuk dan bantuan kepada orang yang membutuhkan (Syafaruddin, 2017: 264).

Pengertian bimbingan secara keseluruhan yang dikemukakan oleh Prayitno dan Amti bahwa bimbingan adalah cara memberikan pertolongan yang dilakukan oleh seorang spesialis atau beberapa orang, baik anak-anak, remaja maupun orang dewasa agar mereka yang dibimbing dapat mengembangkan kemampuan diri dan kemandiriannya, dengan menggunakan kualitas individu dan sarana yang ada selanjutnya, dapat dikembangkan berdasarkan norma yang berlaku (Syafaruddin, 2017: 124).

Kata Agama berasal dari bahasa Sanskrit, terdiri dari dua kata, a = tidak dan gam = pergi. Jadi agama berarti tidak meninggalkan, tetap mendirikan, diturunkan dari satu zaman ke zaman lainnya. Ini menunjukkan salah satu kualitas agama, yang diturunkan dari satu zaman ke zaman lainnya dimulai dari satu zaman lalu ke zaman berikutnya. (Nurhasanah, 2013: 1).

Agama membimbing dan mengarahkan akal. Sehingga dari akal menghasilkan pengetahuan yang tidak lepas dari nilai. Dengan demikian dapat dikatakan bahwa Agama Islam berasal dari wahyu Allah Swt (Une dkk, 2015: 102). Dalam Ensiklopedi Nasional Indonesia terdapat penjelasan tentang agama sebagai aturan atau tatacara hidup manusia dalam hubungannya dengan Tuhan dan sesama (Muniron dkk, 2010: 13).

Dalam buku bimbingan dan konseling islam, editor Aunur Rahim Faqih, pemikiran tentang bimbingan keagamaan Islam adalah cara memberikan pertolongan kepada orang-orang agar kehidupan mereka konsisten sesuai dengan pengaturan dan pedoman Tuhan, sehingga mereka dapat mencapai kebahagiaan. Dalam kehidupan di dunia ini dan di akhirat (Faqih, 2001: 61).

Masa remaja merupakan masa kehidupan yang dimulai dengan 
Ageng RN. Yudi G

perubahan alami pada masa remaja dan berakhir dengan berlalunya individu ke dalam fase perkembangan. Kata "Remaja" berasal dari kata latin adolescene yang berarti to grow (tumbuh) atau to grow up into maturity (tumbuh menuju dewasa) (Elibrahim, 2011: 1).

Pengertian remaja dapat dilihat dari tiga hal, untuk lebih spesifiknya secara berurutan umumnya antara usia 11 atau 12 tahun sampai 18 atau 20 tahun. Sejauh biofisika, masa remaja kemudaan dimulai dengan perubahan pada fungsi fisiologis (termasuk kematangan organ-organ seks) serta penampilan fisik (meliputi tubuh, proporsi tubuh). Untuk sementara, menurut perspektif psikologis, masa remaja adalah masa perubahan dalam bagian-bagian perbaikan termasuk mental, emosional, sosial, seksual, dan lain-lain. Remaja melalui penyelidikan Islam memakai istilah As-Syabab yang berarti masa muda. Sebagaimana diindikasikan oleh syariat Islam, remaja, khususnya individu yang berada pada masa remaja, dikenang sebagai golongan mukallaf, sebagai individu-individu tertentu yang telah menerima beban melakukan kewajiban syari'at. Selain itu, penilaian yang berbeda dari remaja adalah individu-individu yang sudah meninggalkan dunia kanak-kanak dan berangkat menuju pengembangan pada pembentukan tanggung jawab. Hurlock membagi dua masa remaja, khususnya remaja awal berusia 13-16 atau 17 tahun, lalu pra-dewasa akhir yang dimulai pada usia 16 atau 17 tahun hingga 18 tahun (Tim asosiasi psikologi islam, 2020). : 267).

Banyak tokoh yang memaknai masa remaja, misalnya DeBrun mencirikan remaja merupakan masa perkembangan antara remaja dan dewasa. Papalia dan Olds tidak memberikan pemahaman yang tegas tentang remaja namun tentunya melalui gagasan masa remaja. Masa remaja adalah periode perubahan formatif antara masa kanak-kanak dan dewasa yang sebagian besar dimulai pada usia 12 tahun atau 13 tahun dan berakhir pada remaja akhir atau pertengahan dua puluhan. Perkembangan yang dimaksud adalah kemajuan-kemajuan yang terjadi dalam rentang kehidupan. Perkembangan ini dapat terjadi secara kuantitatif, seperti pertambahan tinggi badan atau berat badan dan secara kualitatif, seperti perubahan cara berpikir. Perkembangan dalam 
kehidupan manusia terjadi dalam perspektif yang berbeda (Elibrahim, 2011: 1).

Remaja biasa disinggung sebagai istilah juvenile diperoleh dari bahasa latin juvenilis, yang berarti anak-anak, anak muda, sifat-sifat keremajaan, sifat-sifat masa remaja, sedangkan delinquent berasal dari bahasa latin "delinquere" yang berarti diabaikan, terabaikan, yang kemudian diperluas menjadi berarti jahat, nakal, memusuhi sosial, kriminal, menentang norma, membuat keributan, mengganggu, mengancam, tidak senonoh, dan lain-lain (Suparman dkk, 2020: 182).

Perilaku menyimpang remaja dalam arti kenakalan remaja, seperti yang ditunjukkan oleh ilmuwan sosial Kartono, adalah efek samping gejala sosial pada remaja oleh bentuk pengabaian sosial. Dengan demikian, mereka memupuk suatu jenis perilaku penyimpangan. Perbuatan kenakalan remaja bermacam-macam perilaku remaja yang tidak dapat diterima secara sosial yang menghasilkan tindakan kriminal (Tim Asosiasi Psikologi Islam, 2020: 268).

Sedangkan Sarwono mengungkapkan kenakalan remaja merupakan perilaku menyimpang dari standar hukum pidana, sedangkan Fuhrmann (dalam Sarwono) menyatakan bahwa kenakalan remaja adalah demonstrasi anak muda yang dapat merugikan dan mengganggu dirinya sendiri maupun orang lain. Santrock juga menambahkan kenakalan remaja sebagai berbagai macam perilaku, dari yang tidak dditerima secara sosial menjadi kriminal (Suparman dkk, 2020:183).

Dari pendapat-pendapat di atas, cenderung beralasan bahwa kenakalan remaja adalah kecenderungan remaja untuk melakukan tindakantindakan yang menyalahgunakan prinsip-prinsip yang dapat membawa kemalangan dan kerugian baik bagi dirinya sendiri maupun orang lain. Dalam penelitian ini, penulis memfokuskan kenakalan remaja pada kasus merokok pada usia dini, tawuran remaja, penyalahgunaan narkotik, dan pornografi.

\section{HASIL DAN PEMBAHASAN}


Ageng RN. Yudi G

Remaja islam masjid Baros terletak di Dusun Baros Desa Ciomas Kecamatan Panjalu Kabupaten Ciamis. Data yang diperoleh pada 27 Agustus 2020 dari Usup Sukmana selaku kaur tata usaha dan umum desa Ciomas, Adapun Jumlah Penduduk Desa Ciomas sampai dengan Desember 2018 adalah Dusun Baros memiliki 3 rukun (RW) dengan total 5 rukun tetangga (RT). Jumlah penduduk 756 dengan penduduk laki-laki 411 orang dan penduduk perempuan 345 jiwa. Penduduk dusun Baros 100 persen beragama islam. Mata pencaharian masyarakat dusun Baros dominan sebagai petani, berkebun, pedagang, guru dan ada beberapa yang berkerja ke luar kota.

Mengenai kenakalan remaja yang ada di dusun Baros, Nia Kurniasih sekalu pembimbing remaja islam masjid baros, mengatakan bahwa secara keseluruhan kenakalan yang terjadi masih bisa dikatakan tidak terlalu parah karena kenakalan yang terjadi banyak remaja yang bergaulnya tidak terarah, namun tidak sampai pada pergaulan bebas. Bisa teratasinya kenakalan remaja yang ada di Dusun Baros adalah adanya wadah bimbingan keagamaan khusus semua remaja yang ada di dusun baros yaitu RIMBA.

\section{Program Bimbingan Keagamaan Remaja Islam Masjid Baros}

Menurut Nia Kurniasih selaku pembimbing keagamaan di remaja islam masjid baros mengatakan bahwa program bimbingan keagamaan di remaja islam masjid baros harus ditingkatkan secara berkelanjutan agar para remaja kedepannya terbiasa hidup dalam lingkungan yang beragama dan mempunyai bekal untuk kehidupan dirinya sendiri yang dapat memilih mana yang benar dan salah dikarenakan masa remaja sangat mudah terpengaruh sehingga memerlukan pondasi kuat tentang keagamaan, maka dari itu melalui program bimbingan keagamaan untuk remaja akan membuat mereka terbiasa dalam melakukan kegiatan yang positif. Pelaksanaan bimbingan keagamaan di remaja islam masjid baros mempunyai beberapa program. Adapun program bimbingan Keagamaan di Remaja Islam Masjid Baros sebagai berikut:

Remaja islam masjid Baros memiliki program harian untuk bimbingan keagamaan pada remaja. Berikut ini merupakan tabel program harian di 
remaja islam masjid baros:

Tabel 1 : Program Harian Remaja Islam Masjid Baros

\begin{tabular}{|c|c|c|c|c|}
\hline No & Hari & Kelas & Pelajaran & Pembimbing \\
\hline \multirow{2}{*}{1} & \multirow{2}{*}{ Malam Senin } & Taruna 1 & Jurumiyah & Bapak Jeje \\
\hline & & Taruna 2 & Sejarah Islam & Ibu Nia \\
\hline \multirow[t]{2}{*}{2} & \multirow[t]{2}{*}{ Malam Selasa } & Taruna 1 & Fiqih & $\begin{array}{l}\text { Bapak H. } \\
\text { Abdul Rohman }\end{array}$ \\
\hline & & Taruna 2 & Tauhid & Bapak Yayat \\
\hline \multirow{2}{*}{3} & \multirow{2}{*}{ Malam Rabu } & Taruna 1 & Sejarah Islam & Ibu Nia \\
\hline & & Taruna 2 & Jurumiyah & Bapak Jeje \\
\hline \multirow[b]{2}{*}{4} & \multirow[b]{2}{*}{ Malam Kamis } & Taruna 1 & \multirow{2}{*}{$\begin{array}{lr}\text { Talaran } & \text { Al-Qur'an, } \\
\text { Tawassul } & \& \\
\text { Khataman } & \\
\end{array}$} & \multirow{2}{*}{$\begin{array}{l}\text { Semua } \\
\text { Pembimbing }\end{array}$} \\
\hline & & Taruna 2 & & \\
\hline 5 & Malam Jum'at & \multicolumn{3}{|l|}{ LIBUR } \\
\hline \multirow[b]{2}{*}{6} & \multirow[b]{2}{*}{ Malam Sabtu } & Taruna 1 & Tauhid & Bapak Yayat \\
\hline & & Taruna 2 & Fiqih & $\begin{array}{ll}\text { Bapak H. } \\
\text { Abdul Rohman }\end{array}$ \\
\hline 7 & Malam Minggu & $\begin{array}{l}\text { Taruna } 1 \\
\text { dan } \\
\text { taruna } 2\end{array}$ & $\begin{array}{l}\text { Latihan Kegiatan } \\
\text { Kesenian islami dan } \\
\text { kesenian tradisional } \\
\text { \& PIK-R }\end{array}$ & $\begin{array}{l}\text { Semua } \\
\text { Pembimbing } \\
\text { PIK-R (Pihak } \\
\text { Kecamatan) } \\
\end{array}$ \\
\hline
\end{tabular}

Adapun program mingguan bimbingan keagamaan pada remaja. Berikut ini merupakan tabel program mingguan di remaja islam masjid Baros:

Tabel 2 : Program Mingguan Remaja Islam Masjid Baros

\begin{tabular}{|l|l|}
\hline No & Kegiatan Mingguan \\
\hline 1 & Kesenian Islam \\
\hline
\end{tabular}


Ageng RN. Yudi G

\begin{tabular}{|l|l|}
\hline 2 & Kesenian Tradisional \\
\hline 3 & PIK-R \\
\hline 4 & Olahraga volly \\
\hline
\end{tabular}

Adapun program bulanan remaja islam masjid baros sebagai berikut:

Tabel 3 : Program Bulanan Remaja Islam Masjid Baros

\begin{tabular}{|l|c|c|}
\hline No & Kegiatan Bulanan & \multicolumn{1}{c|}{ Keterangan } \\
\hline 1 & Pengajian bulanan & $\begin{array}{l}\text { Dilaksanakan setiap malam } \\
\text { minggu terakhir perbulannya. }\end{array}$ \\
\hline
\end{tabular}

Kemudian program yang terkahir terdapat program tahunan remaja islam masjid baros sebagai berikut:

Tabel 4 : Program Tahunan Remaja Islam Masjid Baros

\begin{tabular}{|l|l|l|}
\hline No & Kegiatan Tahunan & Keterangan \\
\hline 1 & Ziarah & $\begin{array}{l}\text { Dilakukan sebelum bulan } \\
\text { puasa }\end{array}$ \\
\hline 2 & Kuliah subuh & Selama bulan puasa \\
\hline 3 & $\begin{array}{l}\text { Membimbing pengajian } \\
\text { DTA }\end{array}$ & $\begin{array}{l}\text { Dilaksanakan sampai tanggal } \\
\text { 20 Ramadhan }\end{array}$ \\
\hline 4 & $\begin{array}{l}\text { baros fun competitions } \\
\text { Dilaksanakan pada tanggal 23 } \\
\text { Ramadhan }\end{array}$ \\
\hline 5 & $\begin{array}{l}\text { Pentas seni dan lomba } \\
\text { ceramah }\end{array}$ & Dilaksanakan pada syawal \\
\hline
\end{tabular}

Pelaksanaan Pencegahan Kenakalan Remaja di Remaja Islam Masjid Baros

Bimbingan keagamaan yang dilakukan dalam uapaya pencegahan kenakalan remaja di remaja islam masjid baros dilaksanakan setiap hari kecuali hari jumat. Waktu pelaksanaannya yaitu dimulai dari ba'da magrib sampai isya, dengan mata pelajaran yang berbeda setiap harinya. 
Bimbingan Keagamaan Dalam Upaya Pencegahan Kenakalan Remaja Hasil wawancara dengan Nia Kurniasih mengatakan bahwa dalam pelaksanaan pencegahan kenakalan remaja bagi remaja islam masjid baros pembimbing mengadakan program bimbingan keagamaan untuk remaja. Program tersebut dibentuk dengan terstruktur sudah dalam keadaan disusun atau diatur yang dimana didalam program tersebut sudah disusun dan diatur menjadi program harian, mingguan, bulanan dan tahunan. Terstrukturnya program remaja islam masjid baros ini bertujuan agar memudahkan dalam memberi masukan dari tujuan yang akan dicapai serta mempermudah dalam melaksanakan evaluasi terutama mengenai remaja dusun baros itu sendiri.

Pertama program harian rimba dilaksanakan setiap hari kecuali hari jumat. Waktu pelaksanaannya yaitu dimulai dari ba'da magrib sampai isya, dengan mata pelajaran yang berbeda, seperti pelajaran sejarah islam, tauhid, jurumiyah dan fiqih. Berdasarkan hasil wawancara dengan Nia Kurniasih selaku pembimbing keagamaan di remaja islam masjid baros mengatakan bahwa pelajaran untuk kelas taruna satu dan taruna dua sama hanya berbeda waktunya saja. Adanya pelajaran sejarah islam untuk remaja bertujuan agar generasi muda masa kini dapat mengambil pembelajaran yang sangat berharga dari perjalanan dan perjuanganperjuangan umat islam terdahulu untuk menumbuhkan semangat dan motivasi dalam meningkatkan prestasi umat islam terdahulu dan mengembangkannya dalam kehidupan sekarang ini. Pelajaran jurumiyah agar remaja memahami tata bahasa arab dengan baik, sehingga pemaknaan terhadap bahasa arab tidak keliru. Sedangkan belajar fiqih bertujuan untuk remaja memahami berkaitan dengan tata cara beribadah dan mempelajari ilmu tauhid untuk mendekatkan diri kepada Allah.

Proses bimbingan keagamaan ini dibimbing langsung oleh pembimbing dengan melalui proses tatap muka langsung antara pembimbing dan remaja. Pada tahapan ini seorang pembimbing melakukan pengabsenan kemudian kegiatan bimbingan diawali dengan bacaan doa sebelum mengawali proses pelajaran, pembimbing memimpin doa setelah itu barulah memulai kegiatan penyampaian materi. Saat kegiatan dimulai pembimbing menyampaikan materi sesuai materi yang diampu, setiap remaja memperhatikan apa yang disampaikan oleh pembimbing sambil 
Ageng RN. Yudi G

berjalannya kegiatan remaja diberi kesempatan untuk sesi tanya jawab apabila penyampaian meteri sudah selesai terkadang remaja diberikan tugas oleh pembimbing ketika proses pembelajaran sudah selesai sebelum pulang pembimbing memimpin doa untuk mengakhiri proses pembelajaran.

Adapun proses bimbingan keagamaan yang dilaksanakan hari kamis yaitu talaran Al-Qur' an pada proses ini pembimbing memberikan ayat AlQur'an yang sudah dipilih pembimbing kepada semua remaja denga ayatayat yang berbeda kemudian pembimbing memberikan waktu kepada remaja untuk menghafal ayat Al-Qur'an tersebut, setelah waktunya habis maka remaja akan di tes hafalannya satu orang satu orang. Meurut Nia kurniasih, proses hafalan ayat Al-Qur'an menyesuaikan materi yang sedang dipelajari seperti saat pelajaran sejarah islam tentang dakwah maka remaja menghafalkan ayat-ayat tentang dakwah karena semakin banyak ayat-ayat yang telah remaja hafalkan akan semakin menambahkan kecintaan remaja terhadap Al-Qur'an dan secara otomatis remaja akan sering membaca Al_Qur'an. Begitupun talaran tawasul dan khotaman remaja diberikan arahan mengenai target hafalan kemudian pembimbing mengetesnya satu persatu.

Kedua untuk proses bimbingan keagamaan yang dilaksanakan setiap minggu yaitu ada kesenian yang terbagi menjadi dua bagian yang pertama kesenian islam seperti hadroh kemudian ada kesenian tradisional yaitu gamelan, pada proses ini pembimbing memberikan arahan dan pembagian kelompok dalam kesenian islam hadroh dan kesenian tradisional gamelan, kesenian hadroh itu sendiri sudah tergabung di tingkat Kabupaten Ciamis. Sedangkan kesenian tradisional gamelan para remaja dilibatkan untuk mengikuti kegiatan upacara adat yang akan dipersiapkan untuk menghadapi acara yang ada di Dusun Baros, seperti terdapat undangan untuk mengisi upacara adat di acara pernikahan dan acara lainnya.

Menurut Nia Kurniasih selain belajar bimbingan keagamaan para remaja juga melaksanakan praktek langsung di kehidupan masyarakat sesuai dengan minat dan bakat remaja dengan banyaknya udangan remaja 
sudah dibiasakan untuk bisa menghasilkan dari apa yang remaja itu sendiri lakukan. Selain kegiatan diatas ada juga Bimbingan lainnya seperti Pik-R (Pusat Informasi Konseling Remaja) yang di bimbing langsung dengan pihak kecamatan dengan adanya PIK-R ini remaja diberikan layanan informasi dan konseling tentang perencanaan kehidupan berkeluarga bagi remaja dan kegiatan penunjang lainnya yang sangat penting diketahui oleh remaja.

Untuk program mingguan lainnya terdapat kegiatan olahraga yang dimana olahraga juga sangat penting untuk remaja karena dengan berolahraga akan meningkatkan daya tahan dan sistem kekebalan tubuh selain itu membantu dalam perkembangan kehidupan sosial remaja dan menggali potensi yang dimiliki remaja. Kegiatan olahraga biasa dilakukan oleh remaja islam masjid baros yaitu Volley Ball yang dibantu oleh pihak karang taruna dusun baros. Pada proses ini remaja biasa melakukan olahraga volly pada sore hari di lapangan volly dusun baros, sebelum memulai olahraga remaja melakukan pemanasan kemudian dibagi kelompok, selain olahraga biasa karang taruna baros mengadakan turnamen voly antar dusun dan remaja islam masjid baros selalu mengikuti turnamen tersebut.

Ketiga proses kegiatan bimbingan keagamaan yang dilaksanakan tiap bulan diisi dengan kegiatan pengajian yang dilaksanakan oleh remaja islam masjid baros dan disaksikan oleh semua warga dusun Baros, pada tahap ini pembimbing membagi tugas kepada tiap remaja dengan agenda sebagai petugas MC, pembacaan ayat suci Al-Quran dan Sholawat, pembacaan Tawassul, ceramah, pembacaan Do'a dan kesimpulan oleh Pembimbing.

Pembagian tugas ini dilakukan seminggu sebelum kegiatan pengajian bulanan di laksanakan agar semua remaja yang menjadi petugas bisa mempersiapakan diri terlebih dalulu, pada pembagian tugas pengajian ini teknisnya bergilir artinya setiap remaja akan merasakan menjadi petugas dan tampil didepan hanya perihal waktu saja yang berbeda. Kegiatan pengajian bulanan ini dilaksanakan setiap malam minggu terakhir perbulannya dimulai setelah sholat isya, jadi saat bimbingan keagamaan selesai semua remaja langsung melaksanakan kegiatan pengajian bulanan 
Ageng RN. Yudi G

di Masjid Riyadhul Jannah.

Pada kegiatan pengajian ini pembimbing memerikan pengarahan kepada semua remaja islam masjid baros dan memeriksa kesiapan petugas untuk acara pengajian ini setelah itu, para petugas menempati posisinya masingmasing. Sebelum pengajian berlangsung pembimbing sudah mengumumkan kepada semua masyarakat baros bahwa akan dilaksanakan pengajian bulanan di masjid riyadhul jannah baros, untuk mengingatkan masyarakat dan menuggu semua masyarakat hadir di masjid riyadhul jannah, remaja sudah memulainnya dengan hadroh ketika semua masyarakat sudah berkumpul, selanjutnya acara pengajian dibuka oleh MC setelah dibuka semua petugas bertugas sesuai dengan tugasnya masing-masing sesuai dengan susunan acara yang telah disebutkan oleh $\mathrm{MC}$, setelah kegiatan pengajian selesai pembimbing memberikan kesimpulan dan mengapresiasi penampilan remaja yang sudah bertugas agar remaja semakin semangat lagi selanjutnya acara pengajian ditutup oleh pembimbing.

Menurut Nia Kurniasih, pengajian bulanan yang dilaksanakan untuk remaja islam masjid baros bertujuan agar akhlak semua remaja terbentuk dengan nilai positif yang terkandung pada saat pengajian dengan dibekali ilmu keagamaan pasti akan semakin lebih baik lagi akhlaknya selain itu bertujuan untuk melatih diri remaja agar terbiasa tampil didepan umum dan menjadi remaja yang bertanggungjawab terhadap tugas yang diberikan. Pada saat pengajian bulanan yang disaksikan langsung oleh semua masyarakat baros termasuk orang tua semua remaja, betapa bangganya para orang tua remaja melihat anaknya tampil bisa tampil dalam kegiatan pengajian.

Keempat Selanjutnya untuk proses bimbingan keagamaan yang dilaksanakan setiap satu tahun sekali yaitu dengan kegiatan ziarah ke kapunduhan, Makam Aki Garahang, dan KH. Penghulu Gusti. Kegiatan ziarah masih di wilayah kecaman panjalu dan biasa dilakukan setiap satu tahun sekali sebelum bulan puasa.

Kegiatan selanjutnya dimulai dari bulan puasa sampai bulan Syawal, pada bulan puasa kegiatan dilaksanakan setelah selesai solat subuh 
Bimbingan Keagamaan Dalam Upaya Pencegahan Kenakalan Remaja sampai pukul setengah enam, pada kegiatan bulan puasa ini melibatkan remaja, pembimbing dan semua warga dusun Baros. Kegiatan kuliah subuh ini diisi dengan hafalan juz Amma yang dibawakan oleh DTA tugas remaja adalah menjadi MC untuk membuka acara kuliah subuh tersebut, setelah acara dibuka selanjutnya bersholawat bersama-sama kemudian MC memanggil peserta DTA yang akan tampil dengan disebutkan nama orangtuanya dan disebutkan juga akan membacakan surat apanya. Adapun remaja yang lainnya yang membatu menyiapakan anak-anak DTA yang akan tampil dan memperhatikan bacaan juz Amma yang dibawakan oleh anak-anak DTA.

Ketika semua DTA sudah tampil selanjunya akan diisi ceramah dari remaja islam masjid baros. Ceramah singkat ini dilakukan oleh dua orang remaja setiap harinya, setelah kegiatan ceramah selesai seperti biasa pembimbing menyampaikan kesimpulan dari ceramah yang disampaikan oleh remaja kemudian menutup kegiatan kuliah subuh.

Selain itu remaja juga dilibatkan untuk membimbing pengajian di DTA dengan materi pelajarang sesuai dengan kurikulum DTA yang terdiri dari pelajaran aqidah, sejarah kebudayaan islam, doa harian, hadits, fiqih, dan Al-Qur'an. Pengajian ini dimulai dari pukul 13.00-14.00 pengajian di DTA ini dilakukan seminggu tiga kali dengan pembagian kelompok pada remaja utuk membimbing pengajian di DTA.

Pada bulan puasa, remaja islam masjid baros mengadakan program baros fun competitions yang dilaksanakan pada tanggal 23 Ramadhan yang dilaksanakannya setelah sholat dzuhur dalam kegiatan ini yang menjadi peserta adalah semua DTA. Yang dibagi kelompok menjadi enam kelompok dan perkelompoknya terdiri dari sebelas anggota kelompok, setiap kelompok memakai pakaian yang berbeda-beda dan unik untuk mendukung yel-yel tiap kelompok. Kegiatan ini merupakan berbagai permainan seperti baros pintar yang dimana peserta mendapatkan berbagai pertanyaan mengenai apa yang sudah disampaikan ketika proses pembelajaran sedangkan peserta harus cepat-cepat menjawab, tebak gaya, estafet sarung, estafet air, mistery box dan kursi musik. Pada kegiatan ini peserta mendapatkan hadian dan semuanya mendapatkan sertifikat kegiatan 
Ageng RN. Yudi G

Program baros fun competitions merupakan inisiatif program dari remaja islam masjid baros, program ini sudah berjalan selama dua tahun. Menurut salah satu remaja islam masjid baros diadakannya kegiatan baros fun competitions untuk menguji kekompakan dan pengetahuan anakanak DTA, di program ini diadakan kegiatan yang mendidik tetapi berbentuk diluar ruangan. Selain itu dilaksanakannya di bulan puasa dikarenakan saat bulan puasa remaja islam masjid baros dilibatkan untuk membimbing anak-anak DTA dan kegiatan baros fun competitions inilah yang menjadi acara untuk mengetes hasil selama proses pembelajaran dan sekaligus sebagai penutup pada acara remaja islam masjid baros dalam membimbing pengajian di DTA.

Setelah itu remaja melakukan latihan pentas seni untuk kegiatan di bulan Syawal Pada bulan syawal remaja islam masjid baros terlibat di beberapa kegiatan ada yang menjadi peserta dan menjadi panitia diantaranya pada acara lomba-lomba yang dilaksanakan di bulan syawal seperti lomba tahfidz untuk lomba tahfidz sendiri remaja menjadi panitia karena lomba tahfidz ini untuk tingkat DTA. Adapun untuk remaja sendiri mengikuti lomba ceramah, lomba ceramah ini untuk tingkat remaja dalam lomba ceramah ini dibebaskan untuk siapa saja yang akan daftar mengikuti lomba artinya tidak semua remaja mengikuti kegiatan lomba ceramah tersebut adapun remaja yang ditugaskan langsung oleh pembimbing untuk mengikuti lomba ceramah tersebut. Lomba tahfidz dan ceramah ini merupakan pembukaan untuk acara syawal yang kemudian akan ditutup oleh acara pentas seni. Pada acara pembukaan diawali dengan pembacaan tawasul dan sambutan sekaligus pembukaan acara oleh Bapak Jeje.

Untuk juri kegiatan tahfidz dan ceramah, merupakan juri yang diundang oleh pembimbing artinya yang mejadi juri tersebut merupak orang yang ahli dibidangnya. Ketika kegitan lomba selesai maka semua juri akan mengumumkan hasil kejuaraan saat acara pentas seni yang dilaksanakn di malam harinya. Menutut bapak Jeje, pembagian hadiah saat kejuaraan pada suatu kegiatan atau lomba bertujuan agar anak-anak semakin semangat belajar. Pada acara pentas seni ini Remaja Islam Masjid Baros kelas taruna satu dan taruna dua dibagi menjadi beberapa kelompok dan 
Bimbingan Keagamaan Dalam Upaya Pencegahan Kenakalan Remaja setiap kelompok dibebaskan untuk menentukan pentas seni apa yang akan ditampilkan sesuai dengan kesepakatan setiap kelompok masingmasing, pada acara pentas seni ini Remaja Islam Masjid Baros menampilkan tari Bandung, kabaret, modern dance dan musikalisasi puisi. Kegiatan pentas seni ini dimulai setelah isya dan disaksikan oleh semua masyarakat dusun Baros, kegiatan pentas seni ini merupakan kegiatan yang paling ditunggu-tunggu karena pada bulan syawal ini semua masyarakat dusun Baros yang merantau berkumpul semuannya bersilaturahmi dalam kegiatan ini. Saat pentas seni berlangsung setiap peserta yang tampil akan diberikan saweran oleh penonton, hasil dari saweran tersebut digunakan untuk biaya pendidikkan yang ada di dusun Baros.

\section{Faktor Kendala dan Pendukung Bimbingan Keagamaan di Remaja Islam Masjid Baros}

Keberhasilan suatu kegiatan tidak terlepas dengan faktor pendukung serta faktor penghambat. Adapun yang menjadi faktor pendukungnya pelaksanaan bimbingan keagamaan di Remaja Islam Masjid Baros (RIMBA) adalah: Dukungan dari semua pihak di masyarakat yang sangat mempengaruhi berjalannya kegiatan bimbingan keagamaan di remaja islam masjid baros, seperti masyarakat dan orang tua yang memberikan dukungan kepada anaknya untuk mengikuti bimbingan keagamaan, adanya kesadaran dari remaja untuk mengikuti bimbingan keagamaan, tempat yang jauh dari keramaian, membuat proses bimbingan keagamaan berjalan dengan baik, tersedianya berbagai fasilitas, seperti madrosah dan peralatan hadroh.

Adapun Faktor penghambatnya yaitu: Jika ada dua kegiatan secara bersamaan, maka yang dipilih adalah kegiatan lain bukan mengikuti bimbingan keagamaan dan adanya pengaruh teknologi modern, seperti telepon seluler yang dibawa oleh remaja saat bimbingan keagamaan membuat remaja tidak fokus terhadap materi yang disampaikan oleh pembimbing keagamaan.

Hasil Bimbingan Keagamaan Dalam Upaya Pencegahan Kenakalan Remaja di Remaja Islam Masjid Baros 
Ageng RN. Yudi G

Bimbingan keagamaan untuk remaja sangatlah penting karena, masa remaja yang mudah terpengaruh sangat memerlukan bimbingan keagamaan agar dapat mencegah terjadinya kenakalan remaja yang akan merugikan remaja itu sendiri. Berdasarkan hasil wawancara dengan Nia Kurniasih selaku pembimbing keagamaaan di Remaja Islam Masjid Baros menyatakan bimbingan keagamaan adalah program yang harus ditingkatkan secara berkelanjutan di Remaja Islam Masjid Baros yang mempunyai visi, misi dan tujuan yang baik untuk remaja. Sehingga berdampak baik untuk kehidupan remaja di masa depan. Dengan memperkuat pondasi keimanan remaja agar tidak mudah terpengaruh oleh hal-hal negatif yang akan merugikan dirinya di kemudian hari.

Dengan mengadakan penelitian di Remaja Islam Masjid Baros dapat diketahui pelaksanaan bimbingan.keagamaan.dalam.upaya pencegahan kenakalan remaja di wilayah Dusun Baros Desa Ciomas Kecamatan Panjalu Kabupaten Ciamis. Adanya program bimbingan keagamaan di Remaja Islam Masjid Baros memang harus ditingkatkan secara berkelanjutan, program bimbingan keagamaan ini pembimbing harus mengetahui tentang keadaan remaja sehingga pembimbing dapat menentukan dan memilih program yang tepat untuk mencegah terjadinya kenakalan pada remaja, pembimbing juga mengetahui tentang tujuan yang akan dicapai, sehingga pembimbing dapat memilih materi dan program yang akan dicapai sesuai dengan tujuan tersebut.

Setelah terbentuknya program bimbingan keagamaan pembimbing memberikan nasihat dan dorongan motivasi kepada remaja karena dalam mengumpulkan remaja yang banyak tidaklah mudah untuk langsung menyatukan semua remaja yang ada di Baros perlu proses untuk menyatukannya seperti pemberian nasehat dengan baik dan lemah lembut akan diterima oleh pendengarnya yang akan membuat remaja termotivasi sehingga hati remaja tergugah dan hasilnya remaja mau mengikuti bimbingan keagamaan di Remaja Islam Masjid Baros dan mengikuti semua program yang telah dibuat oleh pembimbing. Untuk pelaksanaan program bimbingan terkadang remaja juga memberikan pendapat seperti menginginkan adanya program tambahan disini 
pembimbing bertukar pikiran dengan remaja untuk mencari titik temu tentang program yang akan dilaksanakan.

Hasil dari bimbingan keagamaan yang dilihat sebelum didirikannya Remaja Islam Masjid Baros dan setelah didirikannya Remaja Islam Masjid Baros terjadi perubahan yang signifikan. Sebelum didirikannya Remaja Islam Masjid Baros remaja Baros banyak yang bergaulnya tidak terarah dan melakukan hal yang tidak bermanfaat seperti nongkrong-nongkrong yang tidak jelas.

Remaja Islam Masjid Baros (RIMBA) merupakan inisiatif yang pas dan mampu mematahkan kebiasaan buruk yang terjadi belakangan ini, Setelah adanya Remaja Islam Masjid Baros Kualitas hidup para remaja sekarang jauh lebih baik dari sebelumnya terlihat ketika para remaja antusias dalam mengikuti kegiatan bimbingan keagamaan, lomba-lomba, pentas seni, olahraga dan kegiatan lainnya yang dilaksanakan dari masyarakat ataupun lembaga lainnya.

Program bimbingan keagamaan Remaja Islam Masjid Baros dibuat memiliki tujuan untuk menciptakan akhlak remaja yang baik. Dari sekian banyak remaja di Dusun Baros sebagian besar mengikuti bimbingan keagamaan, hanya sedikit yang tidak mengikuti kegiatan bimbingan keagamaan karena sudah berkerja atau sekolah di luar Dusun Baros. Adanya Remaja Islam Masjid Baros berdampak baik bagi masyarakat dusun Baros, karena setiap remaja itu memiliki potensi yang hebat dan luar biasa jika diberdayakan dengan baik.

\section{PENUTUP}

Berdasarkan dari hasil penelitian yang telah dilakukan, maka peneliti dapat menyimpulkan hasil penelitian sebagai berikut:

Program bimbingan keagamaan dalam upaya pencegahan kenakalan remaja di remaja islam masjid baros terdiri dari beberapa program yaitu 
Ageng RN. Yudi G

program harian, program mingguan, program bulanan sampai program tahunan.

Pelaksanaan bimbingan keagamaan yang dilaksanakan sesuai dengan program yang ada di Remaja Islam Masjid Baros (RIMBA) itu sendiri diantaranya program harian seperti pelajaran Sejarah islam, Jurumiyah, Tauhid, Fiqih, talaran Alqur'an, Tawassul \& Khataman, untuk program mingguan yaitu latihan kesenian islam seperti hadroh dan kesenian tradisional yaitu gamelan, kegiatan olahraga voly \& Pusat Informasi Konseling Remaja (PIK-R) yang di bimbing langsung oleh pihak kecamatan Panjalu. Selanjutnya untuk program bulanan yaitu pengajian bulanan yang dilaksanakan di setiap malam minggu terkahir perbulannya sedangkan untuk program taunan yaitu ziarah, Baros fun competitions, membimbing pengajian di DTA, ceramah bulan puasa, lomba ceramah dan pentas seni pada bulan Syawal.

Faktor kendalanya adalah adanya pengaruh teknologi modern dan jika terdapat dua kegiatan yang bersamaan.sedangkan faktor pendukungnya adalah adanya dukungan dari semua pihak masyarakat, adanya kesadaran dari remaja, tempat yang jauh dari keramaian, tersediannya berbagai fasilitas.

Hasil dari bimbingan keagamaan dengan terlaksananya program keagamaan di Remaja Islam Masjid Baros (RIMBA) memberikan dampak yang baik terhadap perubahan perilaku remaja Baros dilihat dari sebelum dan sesudahnya didirkan Remaja Islam Masjid Baros.

Adapun keterbetasan penelitian dan saran untuk penelitian selanjutnya yaitu penelitian yang telah dilakukan oleh peneliti memiliki beberapa keterbatasan yang dialami dan dapat menjadi beberapa elemen yang perlu dipertimbangkan kembali untuk penambahan ilmu pengetahuan karena penelitian ini secara positif memiliki kekurangan yang harus direvisi. Kekurangannya yaitu antara lain adalah penelitian yang dilakukan dengan menggunakan metode deskriptif kualitatif yang diperoleh melalui wawancara mendalam. Dalam hal ini peneliti hanya dapat menyimpulkan hasil penelitian dari sudut pandang, yaitu menggambarkan fenomena yang ada di lapangan. Penelitian ini akan 
Bimbingan Keagamaan Dalam Upaya Pencegahan Kenakalan Remaja

lebih sempurna jika ada penelitian lanjutan yang menggunakan dua pendekatan yaitu pendekatan kualitatif dan kuantitatif. Tujuannya agar selain mendeskripsikan fenomena yang ada di lapangan, peneliti juga mengetahui pengaruh antara variabel $\mathrm{X}$ dan $\mathrm{Y}$.

\section{DAFTAR PUSTAKA}

Bakhtiar, Nurhasanah. (2013). Pendidikan Agama Islam di Perguruan Tinggi Umum. Yogyakarta: Aswaja Pessindo.

Elibrahim, M Nur. (2011). Psikologi Remaja. Depok: CV Arya Duta.

Faqih, Aunur Rahim. (2001). Bimbingan dan Konseling Dalam Islam. Yogyakarta: UII Press.

Laning, Vina Dwi. (2008). Kenakalan Remaja dan Penanggulangannya. Klaten: Cempaka Putih.

Muniron dkk. (2010). Studi Islam di Perguruan Tinggi. Jember: STAIN Jember Press.

Suparman. (2020). Dinamika Psikologi Pendidikan Islam. Ponorogo: Wade Group.

Syafaruddin. (2017). Bimbingan Konseling Perspektif Al-Quran dan Sains. Medan: Perdana Publishing.

Tim Asosiasi Psikologi Islam. (2020). Psikologi Islam Kajian Teoritik dan Penelitian Empirik. Yogyakarta: Asosiasi Psikologi Islam.

Astika, S. (2021). Bimbingan Keagamaan dalam Membina Etika Pergaulan Santri Remaja: Iktisyaf Jurnal Ilmu Dakwah dan Tasawuf, 3 (1), 30-55. Jamaludin, O. (2021). Peran Pesantren Salafi dalam Peningkatan Kualitas Akhlak Santri: Iktisyaf Jurnal Ilmu Dakwah dan Tasawuf, 3 (1), 86106.

Badan Pusat Statistik Provinsi Jawa Barat (2016), Diakses 15 April 2020, dari https://jabar.bps.go.id/statictable/2018/03/19/405/jumlahpermasalahan-sosial menurut-jenis-di-jawa-barat-2016.html

world health organization Indonesia (2020), Diakses 10 Januari 2021, dari https://www.who.int/indonesia/news/detail/30-05-2020-pernyataanhari-tanpa-tembakau-sedunia-2020 